\title{
Glosy
}

Andrzej Torbus ${ }^{\text {a) }}$

(D) https://orcid.org/0000-0003-3930-2658

\section{Wykładnia umowy jurysdykcyjnej zawartej na podstawie art. 25 Rozporządzenia Parlamentu Europejskiego i Rady (UE) Nr 1215/2012 Glosa do postanowienia Sądu Najwyższego z dnia 5 października 2018 r., I CSK 611/17}

\begin{abstract}
The choice of court agreement (forum selection clause) is effectively concluded if there is no doubt that the party has actually become acquainted with its content. The Court of Justice of the European Union focuses on those aspects of the conclusion of the contract that allow the assessment that the other party is not surprised by the establishment of a subjective link. The compliance with formal requirements implies that the parties agreed on the conclusion of the contract. There are no objections about so understood "real consent of the parties" as a consequence of fulfilling not only the requirements as to the form, but above all as the way of the conclusion of the contract. The acceptance of the thesis that since the party expressed the undoubted consent to conclude the contract, there is thus no problem of the interpretation of the declaration of intent, is impossible. There is no dispute that the interpretation of a declaration of intent is a legal matter, since the methods of interpretation are determined by the law. According to the Polish Supreme Court, on the basis of Regulation 1215/2012 there is no problem of seeking of the applicable law, because the rules for the interpretation of a jurisdictional agreement should be interpreted from the provision of art. 25 of this regulation. This position is based on the main argument that any deviation from the autonomous rules of interpretation creates the danger that the courts of the Member States will differently determine the law applicable. The Court of Justice of the European Union accepts that an objective
\end{abstract}

a) Dr hab., prof. UŚ, Uniwersytet Śląski w Katowicach. 
(normative) method of interpreting party's statements should be used. In some situations, it is necessary to apply legis causae to effectuate a supplementary interpretation of the declarations of will.

Keywords: choice of court agreement, forum selection clause, interpretation, consent of the parties, declaration of intent, Regulation (EU) No 1215/1212.

\section{Stan faktyczny i stanowisko Sądu Najwyższego w sprawie}

W sprawie polska spółka została pozwana przez sądem polskim przez niemieckiego kontrahenta o zapłatę $\mathrm{z}$ tytułu niewykonania umowy sprzedaży. Strony wiązała umowa dystrybucyjna, której element składowy stanowiła klauzula jurysdykcyjna, na mocy której ustanowiono jako wyłącznie właściwy sąd niemiecki place of jurisdiction dla rozpoznania „każdego przypadku (any case)”. Poza sporem pozostawało, że jurysdykcję krajową w sprawie regulowało rozporządzenie nr 1215/2012 ${ }^{1}$, które w wypadku pozwania podmiotu mającego siedzibę w państwie członkowskim autonomicznie wobec prawa krajowego określa międzynarodowa właściwość do orzekania w sprawie (art. 4 ust. 1) ${ }^{2}$. Rozporządzenie BI-bis określa wymogi skutecznego zawarcia umowy jurysdykcyjnej (art. 25) oraz termin na wniesienie zarzutu braku jurysdykcji (art. 26$)^{3}$.

Pozwana podniosła zarzut braku jurysdykcji krajowej twierdząc, że klauzula jurysdykcyjna dotyczyła sporów bezpośrednio wynikających z umowy dystrybucyjnej. Są I instancji przyjął, że skoro klauzula jurysdykcyjna nie odnosiła się jednoznacznie od umowy sprzedaży, nawet jeżeli ta była powiązana $\mathrm{z}$ umowa dystrybucyjna, to wobec nieoznaczenia stosunku prawnego zgodnie z art. 25 ust. 1 BI-bis wybór jurysdykcji krajowej sądu niemieckiego jest nieskuteczny. W sprawie nie była podważana ani forma umowy jurysdykcyjnej, ani prawidłowe oznaczenie sądu niemieckiego jako forum prorogatum internationalis.

${ }^{1}$ Rozporządzenie Parlamentu Europejskiego i Rady (UE) nr 1215/2012 z dnia 12 grudnia 2012 r. w sprawie jurysdykcji i uznawania orzeczeń sądowych oraz ich wykonywania w sprawach cywilnych i handlowych (wersja przekształcona), Dz.Urz. UE 2012 L 351/1 [dalej: BI-bis].

${ }^{2}$ A. Torbus: Europejski system jurysdykcyjny w sprawach cywilnych $i$ handlowych (Kilka uwag o stosowaniu rozporzadzenia Rady (WE) Nr 44/2001). W: Czterdziestolecie kodeksu postępowania cywilnego. Zjazd Katedr Postępowania Cywilnego w Zakopanem (7-9.10.2005 r.), Red. A. Oklejak. Kraków 2006, s. 298 i n.

${ }^{3}$ A. Torbus: Ustanowienie jurysdykcji sqdów państwa członkowskiego przez wdanie się w spór wedtug rozporzadzenia Rady (WE) nr 44/2001, „Europejski Przegląd Sądowy” 2008, nr 6, s. 11-18. 
Odmienny pogląd przyjął sąd II instancji, który stwierdził, że zarówno umowa dystrybucji i umowa sprzedaży są ze sobą ściśle powiązane $\mathrm{w}$ relacji umowa ramowa versus umowa wykonawcza. $\mathrm{Z}$ tego powodu klauzula jurysdykcyjna zawarta w umowie dystrybucyjnej odnosi się również do sporów z umowy sprzedaży. Należy podkreślić, że sama klauzula jurysdykcyjna była połączona w jednej jednostce redakcyjnej z kolizyjnym wyborem prawa niemieckiego bez wyraźnego i jednoznacznego wskazania stosunków prawnych objętych kognicją fori prorogati internationalis.

Zdaniem Sądu Najwyższego stanowisko sądu II instancji było prawidłowe. W pierwszym rzędzie trafnie została dokonana klasyfikacja i wykładnia umowy dystrybucyjnej, jak można mniemać według prawa niemieckiego. Na podstawie wykładni należało przyjąc wniosek, że umowa dystrybucyjna jako umowa ramowa nieodzownie była powiązana z umową sprzedaży. Sąd Najwyższy przyjął, niewątpliwy nakaz oznaczania stosunku prawnego w umowie jurysdykcyjnej (art. 25 ust. 1 Bi-bis ${ }^{4}$ ) nie należy jednak rozumieć nazbyt restryktywnie. Wystarczy uwzględnienie całości kontekstu ramowej umowy głównej, umowy wykonawczej, skutecznej klauzuli kolizyjnego wyboru prawa niemieckiego dla poprawności wniosku, że wprowadzenie do klauzuli jurysdykcyjnej zwrotu dla „każdego przypadku (any case)” oznacza objęcie jej zakresem wszelkich roszczeń zarówno z ramowej umowy dystrybucyjnej, jak i wykonawczej do niej umowy sprzedaży.

Stanowisko Sądu Najwyższego skupia się na trzech tezach, które prima facie tworza logiczną całość. Punktem wyjścia jest teza, że dla powstanie skutku prorogacyjnego konieczna jest rzeczywista zgoda stron, która powinna być wyrażona dostatecznie jasno i precyzyjnie. Następnie Sąd stwierdził, że wymagania formalne służą właśnie temu, aby zapewnić, że zgoda taka została osiagnięta. Tezą wieńczacca, jest kategorycznie założenie, że zadośćuczynienie tym wymogom implikuje istnienie zgody stron na zawarcie umowy jurysdykcyjnej. Sąd Najwyższy jednoznacznie stwierdził, że kwestia wykładni umowy jurysdykcyjnej również podlega regułom, które należy wyinterpretować z art. 25 BI-bis, a tym samym błędne i zbędne byłoby stosowanie odpowiednich przepisów prawa krajowego (art. 65 k.c.).

Uzasadnienie głosowanego wyroku jest wsparte powołanymi tam tezami orzecznictwa Trybunału Sprawiedliwości Unii Europejskiej [dalej: TSUE], jednakże ich ogólnikowość wymaga doprecyzowania w zakresie odpowiedzi na pytanie czy trafne jest przyjęcie założenia, że istnienie

${ }^{4}$ Verba legis: „spór już wynikły albo spór przyszły mogący wyniknąć z określonego stosunku prawnego". 
rzeczywistej zgody na prorogację jurysdykcji ustala się wyłącznie na podstawie metody wykładni wyinterpretowanej z przepisu art. 25 BI-bis. Niejasne wydaje się rozumienie przyjęte przez Sąd Najwyższy „rzeczywistej zgody stron", która powinna być wyrażona dostatecznie jasno i precyzyjnie wobec oczywistej konstatacji, że w sprawie klauzula jurysdykcyjna była daleka od precyzji, a zastosowana metoda wykładnicza odbiega od subiektywnych teorii oświadczenia woli. Wątpliwości może budzić teza, że spełnienie wymogów formalnych implikuje istnienie zgody stron na zawarcie umowy.

\section{Wymóg ustalenia rzeczywistej zgody stron na prorogację jurysdykcji krajowej}

Kluczowe dla prowadzonych rozważań jest odniesienie się do stanowiska Sądu Najwyższego, że spełnienie warunków formalnych zawarcia umowy jurysdykcyjnej implikuje wyrażenie zgody na prorogacje jurysdykcji krajowej. Następnie ustalenie w jakim zakresie tak rozumiany konsens jest tożsamy z ustaleniem rzeczywistej zgody lub woli stron.

Trybunał Sprawiedliwości Unii Europejskiej wyszedł z założenia, że skoro rdzeniem umowy jest zgodność oświadczeń woli, formy umowy wymienione w art. 25 ust. 1 lit. a-c, ust. 2 BI-bis pełnia funkcje gwarancyjną złożenia oświadczenia woli w taki sposób, że powinny zostać wyeliminowane wattpliwości co do osiagnięcia konsensu. Wykładnia autonomiczna pojęcia formy umowy jurysdykcyjnej pozwala nie tyle na przeformułowanie klasycznego jej rozumienia, ale na rozbudowanie zakresu regulacji art. 25 rozporządzenia BI-bis o kwestie dotyczące dojścia do skutku umowy ${ }^{5}$. Przepisy o formie mają zatem gwarantować, że zgodność oświadczeń woli została osiagnięta jasno i wyraźnie oraz rzeczywiście istnieje ${ }^{6}$.

${ }^{5}$ Powyższe stanowisku znajduje swój wyraz w nieco łagodniejszej formule o podwójnym charakterze przepisów o formie. S. K r ö l l: Gerichtsstandsvereinbarung aufgrund Handelsbrauchs im Rahmen des GVÜ, „Zeitschrift für Zivilprozeß“ 2000, Z. 2, s. 144.

${ }^{6}$ Nie chodzi jednak o ustalenie wszelkimi środkami czy osiągnięto zgodę (porozumienie, konsens), ale że została on osiągnięty „jasno i wyraźnie” (ang. „clearly and precisely”, fr. „une maniere claire et precise”, niem. „klar und deutlich”) i „rzeczywiście istnieje” (ang. „has actually been reached”, niem. „tatsächlich feststeht”). Wyrok TSUE z dnia 14.12.1976 r., w sprawie 24-76, Estasis Salotti di Colzani Aimo e Gianmario Colzani s.n.c. v. Rüwa Polstereimaschinen GmbH. Zb. Orz. 1976, s. 1841, pkt 7; wyrok TSUE z dnia 14.12.1976 r. w sprawie 25-76, Galeries Segoura SPRL v. Rahim Bo- 
Powyższa ogólnikowa formuła powtarzana w kolejnych wyrokach TSUE jest w pełni zrozumiała w wypadkach watpliwości co do rzeczywistego zaznajomienia się strony z treścią porozumienia jurysdykcyjnego, które jest w całości wytworem drugiej strony. Jest to szczególnie uzasadnione w wypadkach realnej nierównowagi gospodarczej miedzy stronami, kiedy strona silniejsza narzuca stronie słabszej własne ogólne warunki umów ${ }^{7}$. Chodzi zatem o wykluczenie zaskoczenia umowną jurysdykcją w następstwie budzacych wątpliwości okoliczności składania oświadczeń woli ${ }^{8}$. To założenie pozwala wyjaśnić szereg konsekwentnych orzeczeń TSUE, w których rozważa się czy ową gwarancję zapewnia wielkość czcionki, chwila przesłania ogólnych warunków zawierajacych klauzulę jurysdykcyjną, odesłanie do klauzuli w umowie głównej, skuteczność wyboru jurysdykcji w razie przesłania faktury, na rewersie której jest umieszczona klauzula jurysdykcyjna ${ }^{9}$. Jednak i w tym zakresie TSUE i sądy państw członkowskich opowiedziały się za liberalną wykładnia. Przyjmuje się, że wymóg zwarcia umowy prorogacyjnej jest spełniony pod dwoma warunkami. Po pierwsze, nie moga istnieć wątpliwości co do możliwości zaznajomienia się z treścia porozumienia jurysdykcyjnego. Ma to oczywiste znaczenie w wypadku, gdy jedna ze stron narzuca własne ogólne warunki umów. Po drugie, nie jest konieczne ani rzeczywiste zaznajomienie się strony z treścią klauzuli jurysdykcyjnej, ani tym bardziej wykazanie tego rodzaju okoliczności. Przykładowo wystarczy, że przed zawarciem porozumienia jurysdykcyjnego w umowie głównej jest wyraźne odesłanie do dostępnych ogólnych warunków kontrahenta,

nakdarian. Zb. Orz. 1976, s. 1860, pkt. 6.; wyrok TSUE z dnia 20.02.1997 r. w sprawie C-106/95, Mainschiffahrts-Genossenschaft eG (MSG) v. Les Gravières Rhénanes SARL. Zb. Orz.1997, s. I-939, pkt. 15; wyrok TSUE z dnia 9.11.2000 r. w sprawie C-387/98, Coreck Maritime GmbH v. Handelsveem BV i innym. Zb. Orz. 2000, s. I-09368, pkt 9, ppkt 1; wyrok TSUE z dnia 7.02.2013r. w sprawie C-543/10, Refcomp SpA v. Axa Corporate Solutions Assurance SA i inni. Elektr. Zb. Orz. 2013:62, pkt. 27; wyrok TSUE z dnia 28.062017 r. w sprawie C-436/16, Georgios Leventis i Nikolaos Vafeias v. Malcon Navigation Co. Ltd i Brave Bulk Transport Ltd. Elektr. Zb. Orz. 2017:497, pkt 34; wyrok TSUE z dnia 7.07.2016 r. w sprawie C-222/15, Höszig Kft. v. Alstom Power Thermal Services, Elektr. Zb. Orz. 2016:525, pkt 37; wyrok TSUE z dnia 8.03.2018 r. w sprawie C-64/17, Saey Home \& Garden NV/SA v. Lusavouga-Máquinas e Acessórios Industriais $S A$, Elektr. Zb. Orz. 2018:173, pkt 25.

${ }^{7}$ Wyrok TSUE z dnia 16.03.1999 r. w sprawie C-159/97, Trasporti Castelletti Spedizioni Internazionali SpA v. Hugo Trumpy SpA. Zb. Orz. 1999, s. I-1648, pkt. 19.

${ }_{8}^{8}$ Zob. postanowienie austr. Oberste Gerichtshof z dnia 30.03.2001r., 7Ob320/00k, ww.ris.bka.gv.at.

${ }^{9}$ A. Torbus: Umowa jurysdykcyjna $w$ systemie międzynarodowego postępowania cywilnego. Toruń 2012, s. 176 i n. 
w tym także umieszczonych na stronie internetowej ${ }^{10}$. Również zawarcie umowy w Internecie poprzez tzw. click wrapping prowadzi do zawarcia umowy jurysdykcyjnej, jeżeli istnieje możliwość wyświetlenia na ekranie tekstu zawierającego klauzulę jurysdykcyjną i jego wydrukowanie ${ }^{11}$.

Nader dyskusyjne jest przyjęcie tezy, że spełnienie wymogów gwarantujących rzeczywiście wyrażenie zgody na prorogację jest tożsame z eliminacją wątpliwości co do wykładni treści umowy jurysdykcyjnej, czy tym bardziej przemawia za subiektywną teoria oświadczenia woli. Odpowiedź na pytanie czy strony osiągnęły konsens nie zostaje udzielona w chwili pozytywnej oceny dochowania wymogów formalnych sposobu zgodnego złożenia oświadczenia woli ${ }^{12}$. Zawarcie umowy przez złożenie podpisów na tym samym nośniku lub przez wymianę pism jest dokonane, jeżeli ustalony sens oświadczeń woli ma tę samą treśćc ${ }^{13}$. W wypadku świadomego nadania różnej treści inkorporowanej w wymienianych pismach dochodzi do dyssensu jawnego. Odmiennie w wypadku zaistnienia dyssensu ukrytego, gdy obie strony błędnie przyjmują, że jednakowo pojęły sens składanych sobie oświadczeń woli ${ }^{14}$. Dopiero proces wykładni pozwoli na ustalenie czy wieloznaczność użytych słów można usunaccéc ${ }^{15}$.

Trybunał Sprawiedliwości Unii Europejskiej koncentruje się na tych aspektach zawarcia umowy, które pozwalaja na ocenę, że druga strona nie jest zaskoczona ustanowieniem łacznika subiektywnego. Z tym zastrzeżeniem czytelna jest teza z uzasadnienia głosowanego postanowienia Sądu Najwyższego, który stwierdza, że spełnienie wymogów formalnych implikuje istnienie zgody stron na zawarcie umowy. Nie budzi zastrzeżeń tak rozumiana „rzeczywista zgoda stron” jako następstwo spełnienia nie tylko wymogów co do formy, ale przede wszystkim sposobu zawarcia umowy ${ }^{16}$. Na marginesie należy wspomnieć, że użyty przez Są Najwyższy czasownik ,implikować” ma raczej znaczenie retoryczne niż logiczne. W orzecznictwie TSUE konsekwentnie powtarzana jest teza,

${ }^{10}$ Wyrok austr. Oberste Gerichtshof z dnia 27.02.2013 r., 60b167/12w, ww.ris.bka. gv.at.

${ }^{11}$ Wyrok TSUE z dnia 21.05.2015 r. w sprawie C-322/14, Jaouad El Majdoub v. CarsOnTheWeb.Deutschland GmbH, Elektr. Zb. Orz. 2015:334, pkt 40.

12 Zob. Z. Radwański: Teoria umów. Warszawa 1977, s. 62, 66-67.

${ }^{13}$ B. Gawlik: Procedura zawierania umowy na tle ogólnych przepisów prawa cywilnego (art. 66-72 k.c.). Kraków 1977, s. 41.

${ }^{14}$ Z. Radwański, w: System prawa prywatnego. T. 2: Prawo cywilne - Część ogólna. Red. Z. Radwański. Warszawa 2008, s. 321.

${ }^{15}$ B. Gawlik: Procedura zawierania.., s. 42. S. Wyszogrodzka: Dyssens $w$ polskim prawie cywilnym. „Kwartalnik Prawa Prywatnego” 2004, z. 4, s. 965.

${ }^{16}$ Opinia rzecznika generalnego M. Szpunara przedstawiona w dniu 7.04.2016 r. w sprawie C-222/15, Höszig Kft. v. Alstom Power Thermal Services, Elektr. Zb. Orz. 2016:224, pkt 33-34. 
że spełnienie warunków formalnych stwarza domniemanie osiągnięcia zgody i może być podważone na zarzut strony ${ }^{17}$.

Bez trudu można zauważyć, że czym innym jest funkcja wymogów formalnych, które mają zagwarantować osiągnięcie konsensu, a czym innym założenie, że forma umowy, sposób jej zawarcia implikuje istnienie rzeczywistego konsensu. Błędna byłaby tezy, że skoro strona wyraziła niewatpliwa zgodę na zawarcie umowy, to tym samym nie istnieje problem interpretacyjny oświadczenia woli. Trafne zatem Sąd Najwyższy odniósł się do kwestii ustalenia właściwej metody wykładni porozumienia jurysdykcyjnego.

\section{Wykładnia oświadczenia woli stron umowy jurysdykcyjnej}

Przepis art. 25 BI-bis nie zawiera żadnych wyraźnych uregulowań co do metody wykładni umowy jurysdykcyjnej. W pewnym uproszczeniu ten przepis reguluje formy zawarcia umowy, minimalne wymogi co do treści zgodnego oświadczenia stron, w tym nakaz oznaczenia stosunku prawnego objętego zakresem porozumienia stron oraz nakaz wskazania sadów lub sądu umownej jurysdykcji. Jedyną wskazówką dla interpretacji umowy jest unormowanie domniemania, że w razie braku odmiennego porozumienia należy przyjąć, że strony ustanowiły umowna jurysdykcję wyłączną (art. 25 ust. 1 zdanie 3 BI-bis). Legislator europejski nie zdecydował się na wprowadzenie autonomicznych wobec prawa krajowego reguł wykładni na wzór art. 8 ust. 2 konwencji wiedeńskiej z 1980 roku $^{18}$. W rozporządzeniu BI-bis nie znajdziemy również jasnego kolizyjnego wskazania prawa właściwego co do wykładni umowy, tak jak w art. 12 rozporządzenia Rzym $\mathrm{I}^{19}$. Nie wykluczam, że właśnie z tej racji w skardze kasacyjnej podniesiono zarzut, że umowa jurysdykcyjna powinna zostać poddana wykładni zgodnej z przepisem art. 65 k.c. właściwego

${ }^{17}$ Odnośnie do domniemania osiągnięcia konsensu zob. m.in. wyrok TSUE z dnia 20.04.2016 r. w sprawie C-366/13, Profit Investment SIM SpA v. Stefanowi Ossiemu i innym, Elektr. Zb. Orz. 2016:282, pkt. 40.

${ }^{18}$ Konwencja Narodów Zjednoczonych o umowach międzynarodowej sprzedaży towarów z dnia 11 kwietnia 1980 r. (Dz.U. z 1997 r. Nr 45, poz. 286). Zob. M. Pazdan: Konwencja wiedeńska o umowach międzynarodowej sprzedaży towarów. Komentarz. Red. M. Pazdan. Kraków 2001, s. 137 i n.

${ }^{19}$ Rozporządzenie Rady (WE) Nr 44/2001 z dnia 22 grudnia 2000 r. o jurysdykcji, uznawaniu i wykonywaniu orzeczeń w sprawach cywilnych i handlowych, Dz. Urz. UE L 12 z 16.01.2001, Polskie Wydanie Specjalne, rozdz. 19, T. 04, s. 42. 
na podstawie ogólnej normy kolizyjnej lex fori processualis. Klasyfikacja umowy jurysdykcyjnej jako rodzaju umowy procesowej może uzasadniać zastosowanie art. 65 k.c. ${ }^{20}$. Inną przyczyną domagania się zastosowania art. 65 k.c. mogło być zasugerowanie się kolizyjnym wskazaniem prawa właściwego zawartego w art. 25 ust. 1 zdanie 2 BI-bis, na podstawie którego nieważność umowy pod względem materialnym ustala się $\mathrm{w}$ myśl prawa państwa członkowskiego. Możliwe jest, że skarżący przyjął właściwość polskiego prawa prywatnego dla ustalenia istnienia konsensu stron.

Poza sporem pozostaje, że wykładnia oświadczenia woli jest kwestią prawna, skoro metody interpretacji określają miarodajne przepisy prawa. W wypadku umów nacechowanych międzynarodowo interpretacja (sensu stricto) polegająca na posługiwaniu się normatywnymi regułami wykładni wymaga uprzedniego ustalenia prawa właściwego, którego kompetencje obejmuja reguły ustalania sensu oświadczenia woli ${ }^{21}$.

Zdaniem Sądu Najwyższego na gruncie rozporządzenia BI-bis nie powstaje problem poszukiwania prawa właściwego, gdyż reguły wykładni umowy jurysdykcyjnej należy wyinterpretować z przepisu art. 25 tego rozporządzenia. To stanowisko znajduje oparcie w zasadniczym argumencie, że każde odstępstwo od autonomicznych reguł wykładni stwarza niebezpieczeństwo odmiennego ustalenia prawa właściwego przez sądy państw członkowskich. Również w orzecznictwie TSUE od lat klaruje się pogląd o zbędności dokonywanie wykładni wedle metod znanych prawu krajowemu państwa członkowskiego forum derogatum lub prorogatum. Kluczowe jest dla tej kwestii orzeczenie w sprawie Anterist, w uzasadnieniu którego TSUE wprost wskazał, że w pierwszym rzędzie wybór jurysdykcji powinien wynikać z brzmienia samej umowy, a dopiero gdy wykładnia literalna nie prowadzi do jednoznacznych wniosków należy uwzględnić okoliczności obiektywne wynikające z treści umowy głównej, jej zawarcia, które pozwalają na ustalenie sensu oświadczenia woli stron $^{22}$.

Oznaczenie sądu właściwego nie musi być nadmiernie precyzyjne, wystarczy wskazanie sądów danego państwa lub miasta siedziby sądu,

${ }^{20}$ Zob. odnośnie do stosowania art. 65 k.c. w wykładni oświadczeń procesowych K. Markiewicz, A. Torbus: O wyktadni pisemnych oświadczeń stron w postępowaniu cywilnym rozpoznawczym, „Polski Proces Cywilny” 2013, nr 1, s. 27 i n. Na temat procesowej natury umowy jurysdykcyjnej zob. wyrok TSUE z dnia 3 lipca 1997 r. w sprawie C-269/95, Francesco Benincasa v. Dentalkit Srl. Zb. Orz. 1997, s. I-3797, pkt 25.

${ }^{21}$ Ł. Żarnowiec, w: System prawa prywatnego. T. 20A: Prawo prywatne międzynarodowe. Red. M. Pazdan. Warszawa 2015, s. 792-793.

${ }^{22}$ Wyrok TSUE z dnia 24.06.1986 r. w sprawie 22/85, Rudolf Anterist v. Crédit Lyonnais. Zb. Orz. 1986, s. I-1967. 
siedziby jednej ze stron, a nawet wskazanie wyłącznie sądu właściwego miejscowo ${ }^{23}$. Dopuszczalne jest wyłącznie wskazanie samego stosunku prawnego bez konieczności opisu sporów z niego wynikających, wykluczone jest jednak abstrakcyjnie wskazanie nieoznaczonych stosunków prawnych łaczaccych strony hic et nunc albo w przyszłości ${ }^{24}$.

Początkowo TSUE opowiadał się za możliwie wysokim stopniem precyzji uzgodnionej treści umowy jurysdykcyjnej, jako że kryteria obiektywne, pozajęzykowe pełniły rolę drugorzędna. Nie sposób zgodzić się z zaletami takiego poglądu. Strony powinny dążyć do formułowania klarownych umów jurysdykcyjnych, a istotne wątpliwości wykluczają osiągnięcie skuteczności porozumienia jurysdykcyjnego ${ }^{25}$. Ma to szczególne znaczenie, jeżeli umowa jurysdykcyjna jest rozbudowana lub wariantowa. W doktrynie francuskiej wskazuje się, że w określonych sytuacjach konieczny jest wysoki standard precyzji (np. ustanowienie umownej jurysdykcji fakultatywnej, wyłączenie tzw. jurysdykcji pochodnej, art. 8 pkt 1 BI-bis ${ }^{26}$. Według innego poglądu w wypadku zawarcia asymetrycznej umowy jurysdykcyjnej na podstawie jej treści, całości umowy głównej, okoliczności jej zawarcia której część stanowi klauzula jurysdykcyjna należy ustalić subiektywną wolę stron ${ }^{27}$. W orzecznictwie szwajcarskim wymóg jednoznaczności tekstu umowy uzasadniano się argumentem, iż forum rei jest przywilejem jurysdykcyjnym, a jego zrzeczenie nie powinno budzić żadnych wątpliwości ${ }^{28}$. Także w doktrynie włoskiej w oparciu o procesową naturę formy umowy został wyrażony pogląd, iż treść umowy musi być nadzwyczaj precyzyjna, tak aby jej sens był oczywisty prima facie ${ }^{29}$. Austriacki Sąd Najwyższy stwierdził za TSUE, że zakres

${ }^{23}$ Wyrok TSUE z dnia 9.11.2000 r. w sprawie C-387/98, Coreck Maritime GmbH v. Handelsveem BV i innym. Zb. Orz. 2000 I-09337, pkt 15.

${ }^{24}$ Wyroki TSUE z dnia 10.03.1992 r. w sprawie C-214/89, Powell Duffryn plc $v$. Wolfgang Petereit. Zb. Orz.1992, s. I-1777, pkt 31; w sprawie C-352/13 z dnia 21.05.2015 r. Cartel Damage Claims (CDC) Hydrogen Peroxide SA v. Akzo Nobel NV i innym. Elektr. Zb. Orz. 2015:335, pkt 68.

${ }^{25}$ P. Ancel, G. Cuniberti: Clause attributive de juridiction. Cour de cassation française (1 ${ }^{\mathrm{re}}$ ch. civ.) 26 septembre 2012, „Journal de Tribunaux” 2013, s. 8-9.

${ }^{26}$ D. Alexandre, A. Huet: Compétence européenne, reconnaissance et exécution: matières civile et commerciale. W: Répertoire de procédure civile, Paris 2016, wersj. elektr. pkt 263. Zob. wyrok Cour de cassation, civile, Chambre civile 1, z dnia 25.03.2015, $\mathrm{N}^{\circ}$ de pourvoi: 13-27.264, www.legifrance.gouv.fr.

${ }^{27}$ D. Martiny, w: Münchener Kommentar zum Bürgerlichen Gesetzbuch. T. 12. Red. J. von Hein, München 2018, Vorbemerkung zu Art. 1 Rom I-VO, nb. 67.

${ }^{28}$ Wyrok szw. Bundesgericht z 23.11.2005, 4C.292/2005, BGE 132 III 268, www. polyreg.ch. Tak również jeszcze w orzecznictwie francuskim do 2015 r. Zob. H. Gaudemet-Tallon: Compétence internationale: matière civile et commerciale. W: Répertoire de procédure civile, Paris 2015, wersj. elektr. pkt 159 i n.

${ }^{29}$ F.P. Luiso: Diritto processuale civile. Principi generali. T. I, Milano 1999, s. 72. 
przedmiotowy umowy jurysdykcyjnej powinien zostać precyzyjnie określony przez strony, a w razie wątpliwości subsydiarnie należy sięgnąć do umowy kreującej stosunek podstawowy ${ }^{30}$.

Umowa podstawowa jedynie pozwala wykluczyć określone watpliwości interpretacyjne klauzuli jurysdykcyjnej. Trafnie ten indykator wykorzystał rzecznik generalny M. Szpunar w sprawie Höszig, uznając że wskazanie sądu właściwego miejscowo dla rozpoznania sprawy transgranicznej między podmiotami z różnych państw członkowskich jest wyborem jednocześnie jurysdykcji krajowej i właściwości miejscowej ${ }^{31}$. W innym orzeczeniu przyjęto stanowisko, że treść umowy jurysdykcyjnej winna wystarczając o wskazywać, który sąd została przez strony wybrana, dopiero wówczas można stwierdzić czy doszło do wyraźnego i jasnego osiagniecia konsensu. To samo dotyczy postanowienia stron, które ustanawiaja jurysdykcję umowna fakultatywna zamiast jurysdykcji wyłącznej. Ustalenie woli stron dokonuje się wyłącznie w oparciu o treść umowy jurysdykcyjnej. Niejasności czy dwuznaczności w tym zakresie powoduja, że umowa jest bezskuteczna ${ }^{32}$. Zdaniem Sąu w Bremen, jeżeli umowa daje wybór jednej stronie do wytoczenia powództwa przez sądem państwowym lub polubownym niezbędne jest precyzyjne i jednoznaczne określenie przesłanek skorzystania z takiego wyboru. ${ }^{33}$ W rodzajowo innej sprawie jeden z niemieckich sądów uznał, że zawarcie równolegle dwóch klauzul jurysdykcyjnych, jednej w umowie podstawowej wskazującej na roszczenia z niej wynikającej oraz drugiej w ogólnych warunkach umów dotyczącej wszelkich roszczeń związanych z umową uzasadnia pogląd, że strony zawarły porozumienie jurysdykcyjne dotyczące zarówno roszczeń kontraktowych, jak i deliktowych ${ }^{34}$.

Omawiany kierunek orzeczniczy znalazł swoją kulminację w wyroku TSUE w sprawie $C D C$. W tej sprawie TSUE przyjął, że wyłącznie wyraźna wola stron decyduje o objęciu umową jurysdykcyjną zarówno roszczeń wynikających z umowy, jak i roszczeń deliktowych z nią powiazanych. Tym samym objęcie zakresem umowy jurysdykcyjnej roszczeń

${ }^{30}$ Postanowienie austr. Oberste Gerichtshof. z dnia 18.12.2014, 2 Ob 217/14x, ww.ris. bka.gv.at. Wyrok TSUE z dnia 24.06.1986 r. w sprawie 22/85, Rudolf Anterist v. Crédit Lyonnais. Zb. Orz. 1986, s. I-1967, pkt. 15.

${ }^{31}$ Opinia rzecznika generalnego M. Szpunara przedstawiona w dniu 7.04.2016 r. w sprawie C-222/15 Hőszig Kft. v. Alstom Power Thermal Services, Elektr. Zb. Orz. 2016:224, pkt 38 .

${ }^{32}$ Postanowienie austr. Oberste Gerichtshof z dnia 28.04.2000, 10b358/99z, www. ris.bka.gv.at.

${ }^{33}$ OLG Bremen, Beschluss vom 28.6.2006 - 2 Sch 3/06, „Zeitschrift für Schiedsverfahren" 2007, H. 1, s. 51.

${ }^{34}$ Wyrok Oberlandsgericht Stuttgart z dnia 08.11.2007 - 7 U 104/0, www.openjur. de. 
kontraktowych wyklucza dochodzenia in foro derogato roszczeń deliktowych, nawet jeżeli szkoda ex delicto ma oczywisty zwiąek z kontraktem głównym. Odrębna wykładnia umowy prowadziłaby do efektu zaskoczenia strony jurysdykcja, która nie została zgodnie wybrana ${ }^{35}$. Inną kwestią dostrzeżoną w polskim orzecznictwie jest sytuacja, kiedy roszczenie deliktowe dochodzone przez stronę in foro derogato może jednocześnie być klasyfikowane jako roszczenie ex contractu. W takiej sytuacji powstaje podstawa do objęcia umową jurysdykcyjną także roszczenia deliktowego, mimo że strony wskazały zakresowo w tej umowie roszczenia kontraktowe ${ }^{36}$.

Na próżno szukać w orzecznictwie TSUE dogmatycznego wyjaśnienia metod wykładni, opowiedzenia się za określona teorią oświadczeń woli. Trybunał balansuje między ogólnikową ideą przewidywalności jurysdykcji, a nader umiarkowanym liberalnym podejściem do wymogów precyzji językowej wyboru jurysdykcji krajowej. Od dawna jednak pojawiały się opinie, że należy położyć nacisk na wykładnie obiektywną. Angielski sędzia A. Havelock zauważył, że tylko wykładnia obiektywna według miernika „inteligencji przeciętnego biznesmena” pozwoli osiagnać ten sam rezultat przez sądy różnych państw członkowskich ${ }^{37}$.

Wydaje się, że orzeczenie w sprawie $C D C$ wieńczy w miarę klarowna linię orzeczniczą TSUE. Do pewnego stopnia można przyjaćc, że wyrażany obiter wymóg pewnej precyzji w formułowaniu klauzuli (umów) jurysdykcyjnych miał gwarantować ustalenie rzeczywistej woli stron. Odmienna optyka został przyjęta przez TSUE w wyroku w sprawie Apple. $\mathrm{W}$ tej sprawie francuski sprzedawca pozwał przed sądem w Paryżu dwie spółki działające w ramach koncernu Apple w związku ze stosowaniem antykonkurencyjnych praktyk i aktów nieuczciwej konkurencji przez faworyzowanie ich własnej sieci ze szkodą dla powoda. Strony wiązała klauzula jurysdykcyjna, na mocy której francuski sprzedawca winien wytoczyć powództwo przed sądem irlandzkim. Strony spierały się między innymi o znaczenie zwrotu „This Agreement and the corresponding relationship", który wyznaczał zakres spraw objętych umową jurysdykcyjną". Rzecznik generalny zaproponował własną wykładnię w oparciu

${ }^{35}$ Wyrok TSUE w sprawie C-352/13 z dnia 21.05.2015 r., Cartel Damage Claims (CDC) Hydrogen Peroxide SA v. Akzo Nobel NVi innym. Elektr. Zb. Orz. 2015:335, pkt 69.

${ }^{36}$ Postanowienie Sądu Najwyższego z dnia 7 kwietnia 2016 r., II CSK 465/15, LEX nr 2231786.

${ }^{37}$ Orzeczenie English High Court, Queen's Bench Division District Registry (Bristol) z dnia 31.10.2008 w sprawie Nursaw v. Dansk Jersey Eksport. „International Litigation Procedure" 2009, Vol. 19, s. 264, 270. Opinia rzecznika generalnego S. Alber przedstawiona w dniu 23.03.2000 r. w sprawie C-387/98, Coreck Maritime GmbH Handelsveem BV oraz inne. Zb. Orz. 2000, s. I-9349, pkt. 30—31. 
o normatywny wzorzec „rozsądnej oceny” dającej się przewidzieć więzi roszczeń z umowy i roszczeń deliktowych powstałych w związku z kontraktem ${ }^{38}$. Trybunał przyjął bez szczególnej potrzeby szerszych wyjaśnień, że wedle kryteriów obiektywnych należało przyjaćc, że tego rodzaju deliktowe roszczenie odszkodowawcze pozostaje w ścisłym i bezpośrednim związku z umową. Innym słowy każdy rozsądny przedsiębiorca nawiązując stosunki umowne z jedną ze spółek koncernu musi przyjąć, że realizacja umowy może zostać powiązana z zachowaniami naruszajacymi reguły uczciwej konkurencji w ramach grupy spółek ${ }^{39}$.

Sprawa Apple wskazuje na dodatkowy aspekt umowy jurysdykcyjnej zawieranej w ramach dużych transakcji międzynarodowych, w których jedna ze stron narzuca korzystny dla siebie wariant asymetrycznego uprzywilejowania. W modelowym ujęciu pactum de prorogando prowadzi do eliminacji alternatywnych łączników jurysdykcyjnych w następstwie ustanowienia jednej umownej jurysdykcji wyłacznej (forum fixing). Szczególnie na rynku finansów międzynarodowych popularne są umowy jurysdykcyjne asymetryczne przewidujące uprzywilejowanie jednej strony (tzw. asymetryczne - otwarte klauzule), która ma możliwość wytoczenia powództwa bądź przed sądami różnych państw lub przed sądem arbitrażowym, a druga strona wyłącznie przed sądem jednego z państw albo tylko przed sądem arbitrażowym ${ }^{40}$.

Stanowisko TSUE w spawie Apple zasługuje na krytyczny osąd, zwłaszcza wobec głoszonego przez Trybunał dążenia do przewidywalności jurysdykcji oraz ustalania rzeczywistej woli stron. Jeżeli strony wprowadzaja rozbudowany, wariantowy mechanizm prorogacyjny, to wówczas należy przyjąć wymóg precyzyjnego wyznaczenia zarówno roszczeń objętych pactum de prorogando, jak i oznaczenia sądów właściwych międzynarodowo. Niestety, mimo powtarzania w kolejnych orzeczeniach TSEU wymogu precyzji w formułowaniu umowy jurysdykcyjnej ma on obecnie znaczenie postulatywne. Zasadność idei przewidywalności jurysdykcji krajowej i tym samym eliminacji walki o forum powinna skłaniać do wyinterpretowania wymogu formalnego jednoznacznego i wyraźnego

${ }^{38}$ Opinia rzecznika generalnego N. Wahla przedstawiona w dniu 5.07.2018 r. w sprawie C-595/17, Apple Sales International i inna v. MJA, działajacej jako syndyk masy upadtości eBizcuss.com (eBizcuss), Elektr. Zb. Urz. 2018:541, pkt. 33.

${ }^{39}$ Wyrok TSUE z dnia 24 października 2018 r., w sprawie C-595/17, Apple Sales International i inna v. MJA, działajacej jako syndyk masy upadtości eBizcuss.com. Elektr. Zb. Urz. 2018:854, pkt 30. D. Schnichels, K. Lenzing, A. Stein: Die Entwicklung des europäischen Zivilprozessrechts im Bereich der EuGVVO im Jahr 2018, „Europäische Zeitschrift für Wirtschaftsrecht” 2019, Z. 21, s. 894.

${ }^{40}$ K. Bälz, P. Stompfe: Asymmetrische Streitbeilegungsklauseln in internationalen Wirtschaftsverträgen: Zulässigkeit, Grenzen, Gestaltungsmöglichkeiten, „Zeitschrift für Schiedsverfahren“ 2017, Z. 4, s. 159. 
formułowania treści w myśl koncepcji claritas $^{41}$. Ta koncepcja nie spotkała się z zainteresowaniem TSUE.

Biorac pod uwagę obecnie dominujace w orzecznictwie TSUE stanowisko, głosowany wyrok Sądu Najwyższego można uznać za wzorcowy. Ogólnikowa, mało precyzyjna klauzula jurysdykcyjna nie była przeszkodą dla przyjęcia skuteczności wyboru sądu innego państwa członkowskiego. Ustalenie sensu oświadczenia woli dokonano w oparciu o kryteria wykładni obiektywnej.

\section{Metoda wykładni według legis fori prorogati lub legis causae}

Według przeciwstawnego poglądu do prezentowanego w głosowanym postanowieniu z przepisu art. 25 ust. 1 Bi-bis wynika nakaz stosowania prawa właściwego fori prorogati także w zakresie wykorzystania miarodajnych reguł wykładni. W przeciwieństwie do art. 23 nieobowiązującego obecnie rozporządzenia 44/200142, de lege lata na mocy art. 25 ust. 1 BIbis stosuje się prawo sądu wybranej jurysdykcji dla ustalenia nieważności umowy jurysdykcyjnej pod względem materialnym (wady oświadczeń woli, pełnomocnictwo, zdolności do zawarcia umowy). Jeżeli prawo właściwe decyduje, że brak konsensu jest przesłanką nieważności umowy, to w tym zakresie to prawo określa reguły wykładni (na przykład złożenie oświadczenia woli dla pozoru $)^{43}$. Według kolejnego poglądu wobec braku regulacji co do metod wykładni w art. 25 BI-bis należy zastosować prawo właściwe. Jest ono relatywnie łatwe do ustalenia, jeżeli przyjmie się, że wybór prawa dla umowy głównej, która zawiera klauzulę jurysdykcyjną

${ }^{41}$ Wyrok Oberlandsgericht Dresden z dnia 02.06.1999, 8 U 55/99, www.iuris.de. W wypadku wymogu formy pisemnej pod rygorem nieważności wykładnię jasnych postanowień umowy wykraczająca poza ich wyraźny sens językowy lub w sposób oczywiście sprzeczny z literalnym brzmieniem należałoby uznać za obejście przepisów o formie. M. Koszowski: „Clara non sunt interpretanda” a wyktadnia umów. Glosa do wyroku SA w Katowicach z 11.3.2005 r., I ACa 1606/04, „Monitor Prawniczy” 2009, Nr 21, s. 1187. Uchwała Składu Siedmiu Sędziów Sądu Najwyższego - Izba Cywilna z dnia 29.06.1995 r., III CZP 66/95, OSNC 1995, nr 12 poz. 168.

${ }^{42}$ Rozporządzenie Rady (WE) nr 44/2001 z 22 grudnia 2000 r. w sprawie jurysdykcji i uznawania orzeczeń sądowych oraz ich wykonywania w sprawach cywilnych i handlowych, Dz. Urz. WE z 2001 r., L 12, s. 1.

${ }^{43}$ H. Dörner, w: Zivilprozessordnung. Kommentar. Red. I. Saenger, München 2019, EuGVVO Art. 25, pkt 25. 
rozciąga się również na porozumienie jurysdykcyjne ${ }^{44}$. Nie pozbawiona praktycznego znaczenia jest propozycja łącznego stosowania metod wykładni przyjętej orzecznictwie TSUE i wynikającej z prawa właściwego ${ }^{45}$.

Wydaje się, że należy jako regułę przyjąć niedopuszczalność stosowania prawa krajowego wskazanego przez miarodajna normę kolizyjną dla ustalenia metod wykładni. Przepis art. 25 ust. 1 Bi-bis zawiera kolizyjnoprawne uregulowanie prawa właściwego (lex fori prorogati) co do ważności umowy (ang. null and void as to its substantive validity, fr. validité est entachée de nullité quant au fond, niem. materiell nichtig) ${ }^{46}$. Założenie, że art. 25 ust. 1 BI-bis zezwala na stosowanie prawa właściwego do kwestii nie podlegajacych autonomicznej regulacji tego przepisu, prowadzi do wniosku, że zakres zastosowania prawa właściwego co do wykładni umowy jurysdykcyjnej jest a priori nader ograniczony ${ }^{47}$.

Odmiennie należy podejść do dopuszczalności kolizyjnego wyboru prawa również dla umowy jurysdykcyjnej, jeżeli porozumienie jurysdykcyjne $\mathrm{w}$ formule klauzuli jurysdykcyjnej jest elementem umowy głównej. Z przepisu art. 25 ust. 1 BI-bis nie wynika wprost dopuszczalność kolizyjnego wyboru prawa dla umowy jurysdykcyjnej. Kompetencja do takiego wyboru wynika z akceptowanej przez eurolegislatora autonomii woli stron dla kształtowania jurysdykcji krajowej ${ }^{48}$. Dodatkowo należy wskazać, że sam wybór jurysdykcji jest klasyfikowany jako jednoczesny wybór prawa dla stosunku głównego (art. 3 ust. 1 Rzym ${ }^{49}$ ). Zaleta takiego rozwiąania uwidacznia się na tle głosowanego orzeczenia. Sąd musiał najpierw dokonać wykładni umowy dystrybucyjnej według prawa wybranego przez stron dla ustalenia zakresu przedmiotu klauzuli jurysdykcyjnej. Poddanie obu umów temu samemu statutowi w zakresie wykładni jest zgodne z wolą stron i zapewnia jednolita metodę ustalenia zgodnych oświadczeń woli. Przeciwko takiej propozycji bez trudu można

${ }^{44}$ R. Gaier, w: Zvilprozessordnung. Beck'sche Online-Kommentare. Red. V. Vorwerk, C. Wolf, München 2019. Brüssel Ia-VO Art. 25, pkt 69.1; P. Schlosser: EU - Zivilprossrecht. Kommentar. Red. P. Schlosser, B. Hess, München 2015, s. 166. Wyrok szw. Bundesgericht z 7 sierpnia 2001, 4C.163/2001, www.polyreg.ch.

${ }^{45}$ P. Mankowski: Anmerkung. Zur Gültigkeit einer Gerichtsstandsklausel bei Benennung einer Stadt eines Mitgliedstaates. EuGH, Urteil vom 07.07.2016 - C-222/15,„Höszig Kft./Alstom Power Thermal Services (Pecsi Törvenysz), "Fachdienst LMK” 2016, Ausgabe 8, Nr. 380737.

${ }^{46}$ Zob. pkt 20 uwag wstępnych do rozporządzenia.

${ }^{47}$ M. Herranz Ballesteros: The Regime of Party Autonomy in the Brussels I Recast, „Journal of Private International Law“2014, Nr 2, s. 303 i n.; U. Mag nus: Sonderkollisionsnorm für das Statut von Gerichtstands- und Schiedsgerichtsvereinbarungen?, „Zeitschrift zur Praxis des internationalen Privat-, Wirtschafts- und Verfahrensrechts” 2016, Z. 6, s. 527.

${ }^{48}$ Punkt 19 uwag wstępnych do tego rozporządzenia.

${ }^{49}$ Zob. pkt 12 uwag wstępnych do tego rozporządzenia 
podnieść argument, że zawsze otwarcie na prawo krajowe zakłóca jednolitość stosowania przepisów rozporządzenia BI-bis.

Wydaje się, że rozwiązaniem kompromisowym jest wykładnia zarówno wedle metod autonomicznej i według prawa właściwego ustalanego na podstawie kolizyjnego wyboru dla umowy głównej i klauzuli jurysdykcyjnej. W procesie wykładni pierwszeństwo będą miały reguły wykładni przyjęte w orzecznictwie TSUE, dopiero gdy wniosek wykładni prowadzi do niepozbawionej watpliwości oceny, że umowa jest bezskuteczna, to in favorem validitatis, uzupełniająco należy dokonać wykładni według legis causae $^{50}$. W sprawie rozstrzygniętej w głosowanym orzeczeniu Sądu Najwyższego zastosowana metoda wykładni obiektywnej pozwoliła na przyjęcie wniosku, że umowa jurysdykcyjna doszła do skutku, a tym samym sięganie do prawa wybranego przez strony było zbędne.

Właściwość prawa krajowego dla wykładni umowy jurysdykcyjnej wydaje się bezsporna, jeżeli istnieje konieczność zastosowania tego prawa na podstawie przepisów innego aktu prawa unijnego. W wypadku klauzul jurysdykcyjnych zawieranych z konsumentami (art. $19 \mathrm{w}$ zw. $\mathrm{z}$ art. 25 BI-bis) niejasne postanowienia umowy jurysdykcyjnej prowadzą do jej bezskuteczności na podstawie prawa krajowego, który implementował art. 5 dyrektywy $93 / 13^{51}$.

Biorąc powyższe rozważania pod uwagę glosowane postanowienie Sąu Najwyższego jest $\mathrm{w}$ pełni zgodne $\mathrm{z}$ aktualna linią orzeczniczą TSUE. Zastosowana wykładnia obiektywna oparta na wzorcu „rozsąnej oceny" przyjętej w stosunkach gospodarczych pozwoliła na wniosek, że klauzula jurysdykcyjna dotyczy roszczeń wynikających z umowy dystrybucji i powiązanej z nią umowy sprzedaży.

${ }^{50}$ Wyrok szw. Bundesgericht $z$ dnia 21.09.2017., 4A_131/2017, www.polyreg.ch.

${ }^{51}$ Wyrok Oberlandesgericht Wien z dnia 28.05.2019, 129 R 37/19p, www.beck-2online-1beck-1de. Dyrektywa Rady 93/13/EWG z dnia 5 kwietnia 1993 r. w sprawie nieuczciwych warunków w umowach konsumenckich, Dz. Urz. L 095, 21/04/1993 P. 0029—0034. 